\title{
Daily Patronage Politics: A Village Chief's Route to Power
}

\author{
Devy Dhian Cahyati ${ }^{1}$ and Yonatan Hans Luter Lopo ${ }^{2}$
}

Received: 15 April 2019 | Accepted: 14 October 2019 | Published: 20 November 2019

\begin{abstract}
This article discusses the politics of patronage used by incumbents in contesting village chief elections. Through observations and interviews conducted before and after the 2018 village chief elections in Klangor Village, Galur District, Kulon Progo Regency, the researchers explored the strategies used by the incumbent to contest the election and seek re-election. At the village level, the politics of patronage function differently than at higher levels of government. The authors argue that incumbents do not only create patronage networks during elections, during which voters are provide money or other gifts; they create patronage networks during their everyday activities. Using the economic resources available to them, incumbents combine three approaches to patronage: benevolence politics, scare-off tactics, and money politics. In this article, the authors argue that the incumbent redefined money, transforming it from a means of conducting transactions into a means of appreciating and rewarding voters. By using this strategy, incumbents can guarantee supporters' loyalty and receive their votes.
\end{abstract}

Keywords: patronage, village chief elections, gifts, vote buying, economic base, benevolence politics

\section{Background}

This article explores the politics of patronage that are implemented by incumbents in their everyday lives before being converted into political support during elections. Studies of politics at the village level have become increasingly important since the ratification of Law No. 6 of 2014 (henceforth the Village Law), which granted villages broad authority (including in financial

Researcher at the Research Centre for Politics and Government (PolGov), Department of Politics and Government, Faculty of Social and Political Sciences, Universitas Gadjah Mada.

2 Researcher at the Research Centre for Politics and Government (PolGov), Department of Politics and Government, Faculty of Social and Political Sciences, Universitas Gadjah Mada. 
matters). Studies of patronage at the regency and provincial level have framed it as a distributive exchange between politicians and their supporters during electoral campaigns (Aspinall \& Sukmajati, 2015; Gallego, Li, \& Wantchekon, 2018; Simandjuntak, 2015). This study, which examines patronage at the village level, finds that the practice occurs not only during electoral campaigns, but also in everyday exchanges and interactions. Through their everyday interactions with their constituents, village chiefs receive public support that they transform into electoral support during elections. This will be argued by taking the 2018 village chief elections in Klangor Village, Kulon Progo Regency, as its case study.

Patronage is a common practice, including in Indonesia, where a study by Aspinall \& Sukmajati (2015) showed that - although some candidates reject money politics - patronage has become a central component of many campaign strategies. Patronage has taken diverse forms, including the provision of money to individual voters and the gifting of public goods to social groups and organisations (Fikri, 2017).

A number of studies have examined patronage as practiced by parties and politicians at the regency and national level (Berenschot, 2018; Aspinall \& Sukmajati 2015; Aspinall, E., \& As'ad, M. U, 2015; Fikri, 2017). This article, meanwhile, will explore the practice of patronage at the lowest level of government, the village level. It cannot be denied that village-level elections differ significantly from those at the municipal, provincial, and national levels. Candidates seek office in relatively small areas, and thus are expected to establish good relations with their constituents. This article argues that, to become village chief, candidates must establish paternalistic relationships not only during their campaigns but also in their everyday activities and interactions. Unlike candidates at the municipal, provincial, and national level, village chief candidates cannot simply approach voters during their campaigns. They must establish strong networks with constituents, create a and maintain a working relationship that endures even after the election. 
In the midst of this political pragmatism, during which candidates only establish paternalistic relationships during elections, it is interesting to study the practice of patronage in Klangor Village. In this village, the chief began establishing paternalistic relationships with constituents long before being elected, using his background in the sand mining industry to establish strong personal ties with constituents (most of whom were manual labourers). These relationships were maintained throughout his first term as village chief, during which he interacted freely and regularly with constituents of all social classes and backgrounds. In the 2018 village chief elections, while still maintaining paternalistic relationships with constituents, he also threatened "turncoats" (former supporters who indicated that they would vote for another candidate) and discriminated against village staff who refused to support him.

To examine the practice of patronage in Klangor Village, research was conducted in the village over the course of one month (during the two weeks before the election and the two weeks after the election). Interviews were conducted with key informants, including candidates, campaign team members, village government staff, and village residents. Participatory observation was also employed to collect data on the candidates and their campaign activities.

This article consists of six sections. The first section describes the topic and main arguments of this paper. The second section provides a review of relevant studies into the practices of patronage and clientelism in village elections. The third section explores the socio-cultural setting of Klangor, its people, and its elections. In the fourth section, this article delineates the process through which patron of Klangor emerged, ending the previous dynasty. In the fifth section, this article describes the practice of patronage in Klangor's 2018 elections. Finally, the sixth section presents this article's conclusions, its findings, and its theoretical implications. 


\section{Literary Review}

Patronage has been widely studied by academics from diverse disciplines. Anthropologists, for example, have focused on analysing how people with different levels of authority manipulate their personal relationships to realise shared interests (Weingrod, 1968). They have framed patronage as involving uneven interpersonal relationships between patrons (persons with economic and political capital) and clients (persons lacking such capital) (Van Klinken, 2009; Weingrod, 1968). For anthropologists, patronage does not necessarily involve government or formal power; rather, informal relationships are key (Weingrod, 1968). Meanwhile, political scientists understand patronage as politicians and political parties' distribution of resources and public offices in return for political support during election campaigns (Weingrod, 1968). Unlike anthropologists, who see patronage as involving long-term relationships, political scientists understand patronage as being limited to electoral campaigns (Weingrod, 1968; Hanif, 2009).

Other studies, such as that by Pappas (2009), have shown that patronage has become an important part of contemporary politics and that it has been facilitated by modern political systems, ideologies, and masses. Patronage is deliberately employed by political actors to gain voter support and thereby access power. It becomes possible when candidates and political leaders are capable of controlling organisations and choosing office holders. In such situations, ideologically motivated candidates are conditioned to become patrons that advance their own interests.

Patronage has been widely used in electoral contestations, and Aspinall \& As'ad (2015) have identified a strong correlation between patronage and electoral victory. Electoral democracy has offered an arena in which candidates (patrons) can compete in various ways. For example, Lindber (2003) has found that general elections in Ghana exacerbated (rather than ameliorated) the reproduction of neo-patrimonialism, arguing that the tradition of giving gifts, as well 
as high levels of poverty and low levels of education, have combined to create a new form of paternalism. Aspinall \& Sukmajati (2015), meanwhile, have provided a detailed examination of the politics of patronage in Indonesia's 2014 legislative elections, finding that paternalistic relationships were created through vote buying, club goods, and pork barrel projects, as well as the distribution of government projects and offices to campaign team members.

In discussing the continued practice of patronage in democratic systems, Shin (2015) has argued that patronage has been seen through two main paradigms. The first holds that patronage is driven by public demand, by poor voters promoting their individual interests. The second, meanwhile, views patronage through a supply lens, arguing that - as few politicians offer pragmatic policiesvoters are required to support politicians who employ paternalistic ones. Shin (2015), meanwhile, finds that uneducated voters are more likely to support patronage over policy, as they desire jobs, money, education, and healthcare. Shin also argues that political participation is a core component of patronage, with voters being more willing to accept paternalism if they have previously supported a candidate and/or party. More specifically, Tomsa \& Ufen (2013) understand patronage as involving the use of state resources to gain voters' political support.

The practice of patronage cannot be separated from the practice of clientelism, even though the term "clientelism" itself remains controversial (Hanif, 2009). Generally, clientelism refers to the exchange and provision of state resources to non-state agents without a policy basis. Exchanges between politicians and their supporters may be identified as clientelistic when supporters are provided resources (or access to such) in return for their political support (Aspinall \& Sukmajati, 2015; Berenschot, 2018; Hopkin, 2006). In other words, clientelism is often understood as a form of personal exchange, one often characterised by a sense of obligation and an uneven distribution of power (see Eisenstadt and Roniger 1984: 48-49; Piattoni 2001. Such a definition reflects the origins 
of the concept, which was first used to describe the patron-client relationships and hierarchies in traditional villages (Piattoni 2001, p. 9), wherein patrons would provide clients to basic services and facilities in exchange for their goods/services (labour, crops, etc) and their respect and loyalty (Mason 1986, p.489). According to Hopkin (2006), the term clientelism has negative connotations, as it infers a culturally and economically "backwards" society despite also occurring in more culturally and economically "modern" societies (as seen in developed countries' pork barrel policies).

It has been particularly common for incumbents to utilise state resources to win elections and therefore remain in office (Grzymala-Busse, 2008). Incumbents are also able to use scare-off tactics, especially against potential competitors. As explained by Cox \& Katz (1996), incumbents have the ability to mobilise state resources to strike fear into the hearts of their potential opponents or otherwise limit said opponents' ability to contest elections.

In Indonesia, several studies have explored patronage within the context of benevolence politics. Latief (2013a), for example, has shown that the paternalistic activities of charitable and political organisations have detrimentally affected Islamic groups' ability to effect collective change. At the same time, the paternalistic use of charitable activities has been unable to guarantee voters' electoral support (Latief, 2013b; Hanif, 2009, in Latif, 2013b).

Studies dealing specifically with democracy at the village level, such as that by Prijono, Yumiko, \&Tjiptoherijanto (1983), have also shown that patron-client relationships-built upon a foundation of land ownership and distribution - exist between village leaders and their constituents. Prijono, et al. (1983) argues that the involvement of village residents (many of whom are farmers) in village discussions only serves to limit their power and perpetuate their subjugation, finding that democracy regressed significantly during the 1970s as elites gained control of lands that had previously been owned communally.

From these studies, it is clear that various forms of political 
patronage continue to be practiced in democracies around the world, as it is often seen as a means of quickly and effectively gathering public support. Studies of political patronage have generally focused on the links between voters and candidates/political parties during elections. Few, however, have examined the practice of patronage in village elections. These have included studies of village-level elections in Indonesia-in Southeast Aceh Regency (Andhika, 2017), Ngawi Regency (Khusni, Sardini, \& Kushandayani, 2018), and Bulukumba Regency (Ramli, 2016) - as well as Mexico (Buve, 1992).

Building on these previous studies, this article seeks to explore the practice of political patronage in village-level elections, where paternalistic practices differ from those at the municipal, provincial, and national level. Complementing existing studies of patronage, this article argues that intense paternalistic interactions are not limited to elections, but rather involved in intense everyday interactions. It shows that patronage is practiced by candidates, campaign staff, and supporters through a combination of benevolence politics, scare-off tactics, and vote buying.

\section{Village Profile and Election Context}

Klangor Village-pseudonymised here for confidentiality purposes-is located in Kulon Progo Regency, Yogyakarta, a provincial-level autonomous region. Still ruled by its traditional sultanate, this region's special autonomy has had significant implications for village politics and for village-province relations. Klangor was one of numerous villages that held elections in 2018.

Given its strategic position between Yogyakarta City and other regencies, as well as its location at the centre of Galur District, Klangor has a vibrant economy that is driven primarily by agriculture, trade, and industry. The village government contributes to this economy, operating its own kiosk near the market.

Klangor is administratively divided into ten padukuhan, four of 
which have no agricultural land. Home industries, thus, are primary drivers of these economies, and the local government has facilitated residents through training sessions and other skill-building activities. Elsewhere, agricultural activities - complemented by trade-have provided residents with sufficient income to support themselves and their families.

Owing to its location along the Progo River, Klangor also has access to significant natural resources. The most important of these is sand, which is excavated by individuals and companies before being sold as a construction material. Initially, this sand was excavated manually by village residents. Over time, as the sand mining industry grew and technology advanced, sand suction pumps began to be used, followed later on by heavy equipment such as backhoes. Klangor has since become known as one of Yogyakarta's best sources of sand, and many of its residents rely on the Progo River for their livelihoods.

As of writing, the Klangor Village government has been led by six village chiefs, with their terms divided as follows:

1. Raden Parwono (served 1925-1938)

2. Sumaryono (1938-1947)

3. Harjo Santoso (1947-1955)

4. H. Adiwilaga (1955-1989)

5. Soemarso (1990-1998; 2002-2009; Soemarso resigned in 2009 to run for local parliament).

6. Aswin (2010-present)

Of the six village chiefs who have led Klangor since 1925, the first five came from the same trah, or family (Soemarso, interview, Oct 10, 2018). This dynasty only ended after Aswin was elected in 2010, having used patronage to gain widespread support.

For its 2018 election, Klangor had seven polling stations and 3,663 registered voters. Initially, eight individuals registered as candidates. However, only five passed the selection process. The first candidate on the ballot, Giharto, was a former electric 
company employee who had joined the Golkar Party in 1976. After retirement, this candidate began working a rice paddy in Klangor. Giharto stated that he was running for village chief in order to keep a vow he had made. However, he was not seen as a serious candidate, as during the campaign he had made no effort to gather public support.

Second on the ballot was Aswin, the incumbent. Aswin was seen as the strongest candidate, both because of his political experience in the village and his access to financial capital. Aswin had long worked in the sand mining industry, renting trucks to miners and other parties.

The third candidate was Jiwan, the secretary of the Klangor Village Council. Jiwan was known as a good, kind, and polite man, and as the takmir (attendant) at Muqorobin Mosque. Given this background, many of Jiwan's supporters were mosque members and devout Muslims. Jiwan had applied for a position in the village government several times, including in its general affairs bureau (Jiwan, interview, Oct 10, 2012), but failed. In 2014, he became a member of the village council. He subsequently attemptedunsuccessfully - to become the dukuh of Gebang in 2017 and the village secretary. Jiwan did not have a formal campaign team, but nonetheless a number of his supporters attempted to influence others and gather votes.

The fourth candidate on the ballot was Pradana, the youngest candidate to contest the Klangor election. The initiator of the Klangor Information and Creative Potential System (Sistem Informasi dan Potensi Kreatif Desa Klangor, SIPKADES), Pradana used this programme to mobilise the village youths. He was a member of the same family as Soemarso, who had served as chief of Klangor between 1990 and 2008.

Fifth on the ballot was Sudarmadi, a member of the Prosperous Justice Party (Partai Keadilan Sejahtera, PKS) who worked as a construction worker. After Sudarmadi failed to gain office as the dukuh of Curup Kidul, he was widely urged to contest the election. 
Sudarmadi was considered an "innocent" in village politics, and his political activities were understood as having been sponsored by his party and inspired by his father (Suprono, interview, Oct 8, 2018).

Although the Klangor election was formally contested by five candidates, only three were seen as serious contenders: Aswin, Jiwan, and Sudarmadi. Pradana was seen as lacking the ability, authority, and economic capital to contest the election; similarly, he lacked the support base necessary to gain public attention. As such, his candidacy was seen as a means of gaining access to public resources. Meanwhile, Giharto had significant economic capital, but failed to make a serious effort to gain public support. He intended solely to keep his vow to run for village chief (Anwari, interview Oct 13, 2018; Jiwan, interview, Oct 10, 2018; Mulyono, Interview, Oct 13, 2018). ${ }^{3}$

\section{The Rise of the Patron}

In Javanese culture, a trah is a hereditary family structure, one that covers multiple generations. This is an important factor in leadership; traditionally, questions of heritage and family history are considered carefully when choosing a leader (Endraswara, 2013). Between 1925 and 2009, Klangor had been run by men from the same line. As such, Aswin's electoral victory in the 2009 election was phenomenal, something unprecedented in village history. This victory, however, was not spontaneous; it was the result of a long and difficult process.

Aswin had been born and raised in Bantul, only becoming a resident of Klangor in 2000. His parents had been teachers in Galur District, and Aswin had attempted to follow in their footsteps before determining that he was unsuited to the field and that a teacher's wages could not support his family. He then decided to enter business, travelling to Jakarta and working for a migrant labour placement service. He also spent time working as a driver and as an

Anwari was member of Sudarmadi campaign team. Mulyono did not pass the selection process. 
automotive reseller; in this capacity he travelled to Sumatra, Bima, and even Saudi Arabia.

Aswin ultimately decided to return to Klangor and work in the sand mining industry, a major driver of the local economy. Through his involvement in the sand mining industry, Aswin began regularly interacting with local residents. He also established close ties with political actors, grassroots organisations, and activists at the village, municipal, and provincial level. This enabled him to become not only a political actor, but also a serious contender in Klangor's 2009 village election. He ultimately won this election and replaced Soemarso, who had served as village chief since $1990 .{ }^{4}$

It may thus be concluded that Aswin's victory in the 2010 village election can be attributed to several factors. First, he had access to significant economic resources, operating several "sand depots" that employed numerous village residents, ${ }^{5}$ he also owned numerous trucks that were rented by private enterprises and the government for construction projects. His involvement in such activities not only provided him with significant financial capital, but also good networks with people from various social backgrounds, including miners and other residents. His was one of the richest families in Klangor, and Aswin used this to improve his electability. He spent a significant amount of money during the 2009 village election. ${ }^{6}$ As there are no regulations requiring village chief candidates to disclose their net worth, no official figures have been disclosed. However, data collected by the research team indicated that Aswin was the second wealthiest of the five candidates contesting the 2018 election (Sudarmadi was the wealthiest).

4 In 2008, Soemarso resigned from his position as Chief of Klangor Village in order to run for a seat in the Kulon Progo Local Parliament.

5 These sand depots are located near the Progo River. Sand mined from the river is subsequently sold as construction material.

6 Interview with a member of the Klangor Village Council. 
Second, Aswin was known for his personal generosity and his willingness to interact with people from various backgrounds, frequently treating his friends to meals and distributing money amongst his colleagues. In other words, he was known for practicing benevolence politics, using his financial capital to facilitate his interactions with his constituents and gather their sympathy. Through his years as an entrepreneur, he had developed an ability to establish and maintain close relations with others, relying on his charisma and his willingness to spend money. In return, he expected his clients to show loyalty and support for him. Such patron-client relations enabled Aswin to better utilise his resources and mobilise support for electoral purposes. His belief that he could win the election bore fruit; in the 2009 election, Aswin received 1,780 votes $(62.92 \%)$, more than twice as many as the runner-up (Anonymous, 2010).

The patron-client relations established through Aswin's everyday interactions were not his sole means of gaining voter support during Klangor's 2009 election; he also employed paternalistic strategies during his campaign. Several informants indicated that, on the day of the election, Aswin's campaign staff had left money-stuffed envelopes at the doorsteps of voters' homes (Sudarmadi, interview, Oct 12,2018). He did not mind using vote buying to get electoral support, as being village chief would give him prestige that he could use in his business negotiations (Aswin, interview, Oct 9, 2018).

Aswin's business background, as well as his benevolence, generosity, and willingness to interact with people from all social backgrounds, affected his leadership style. During his first term (2010-2016), he was seen as employing an informal leadership style, both in his own activities and in his administration. Rather than hold formal meetings, which were full of ceremony and pomp, Aswin preferred informal gatherings. Many informants stated that Aswin generally refused to sit in the front during thanksgiving ceremonies, prayer recitations, and social activities. By bucking tradition, Aswin 
gained the loyalty and trust of his constituents, who viewed him as a humble man, a "people person". This public belief was cemented by Aswin's willingness to meet with constituents and discuss official matters at his home; in emergencies, he was even willing to sign official documents in the streets or while travelling (Luhung, interview, Oct 15, 2018). ${ }^{7}$

In his efforts to develop the village, Aswin initiated a number of programmes. He worked to develop available infrastructure, build a new Village Hall, and-with funding from the Yogyakarta Environmental Agency (Badan Lingkungan Hidup Yogyakarta)create a rest area along the Progo River. Aswin also promoted Klangor as a cultural village (Maryadi, interview, Oct 1, 2018). Such projects were made possible by Aswin's close professional and personal relationship with neighbouring villages, district officials, and municipal agencies. In this, he closely resembled other village chiefs from entrepreneurial backgrounds who could readily access government projects. He dedicated himself to lobbying the municipal, provincial, and national governments, thereby gaining access to various projects. For example, through the Cultural Village Programme, Klangor received a new stage for its cultural activities (funded by the Yogyakarta Provincial Government), while through the Dilapidated Home Programme it received financial support from the municipal government of Kulon Progo (Aswin, interview, Oct 9, 2018).

Because of his leadership style, as well as his success developing Klangor, Aswin found many loyalists both within the village government and within the community. Voters continued to support him, as they believed that he had made significant breakthroughs. His patronage during Klangor's 2018 election, thus, had not emerged suddenly. He had significant financial capital, which he employed through benevolence politics to gather voters' support. His capital and patronage, as well as his tendency to act

Luhung was member of Aswin Campaign team. 
informally, his openness, and his ability to access government projects made him a favourite in Klangor's 2018 election.

\section{Klangor's 2018 Village Election: Sophisticating Political Patronage}

Several days before the election, Aswin stated "kalau menang ya syukur... kalau kalah itu kebangetan" (If I win, I'll be grateful; if I lose, it's unacceptable). This implied that he strongly believed that he would be re-elected for the 2018-2024 period. Despite having served as a patron for over a decade, he did not rely solely on benevolence politics and money politics; he also used scare-off tactics to frighten both his political opponents as well as potential "traitors". Seeking to guarantee his electoral victory, he employed various strategies and practiced a more sophisticated patronage. He recognised the shifts that had occurred in Indonesian politics, including the need to control the flow of information, stop rumours from spreading, mediate between various political actors, and buy votes. He was thus a favourite in the 14 October 2018 election, having converted the seeds he had sown through patronage into voter support and electoral victory. His electoral victory resulted from various factors. First, the patronage networks that he created with campaign staff and supporters. Second, his personal capacity as a patron, including his ability to mediate with groups across the political spectrum. Third, his ability to control the flow of information through political networks and stop the dissemination of rumours. Fourth, the incumbent not only established patronage networks through his everyday interactions with constituents, but also through his campaign activities and provision of money and club goods to voters. This is discussed in detail below.

First, Aswin created and maintained strong relationships with his campaign staff and his voters. After beginning his first term as village chief in 2010, the incumbent continued to interact with his campaign staff and rely on them for his benevolence politics. 
During the 2018 election, rather than create a new team, he chose to reactivate the political machine that had brought him electoral victory (Sungkono, interview, Oct 25, 2018); Luhung, interview, Oct $15,2018)$. After completing his written test, the incumbent called upon the friends and colleagues who had helped him in the previous election. This included more than 100 people, who were spread throughout the village, including in padukuhan that were expected to support one of his opponents. In campaign activities, the incumbent played a central role, determining the campaign's use of information, money, and strategies in an effort to achieve political victory. Under Aswin, this campaign team had a coordinator who was charged with managing the "core cadres" in the padukuhan of the village. In turn, these core cadres had to coordinate cadres, individuals who were expected to reach 5-20 voters each. The structure of the campaign team is shown in Figure 1 below:

Figure 1. Structure of the Aswin Campaign Team ${ }^{8}$

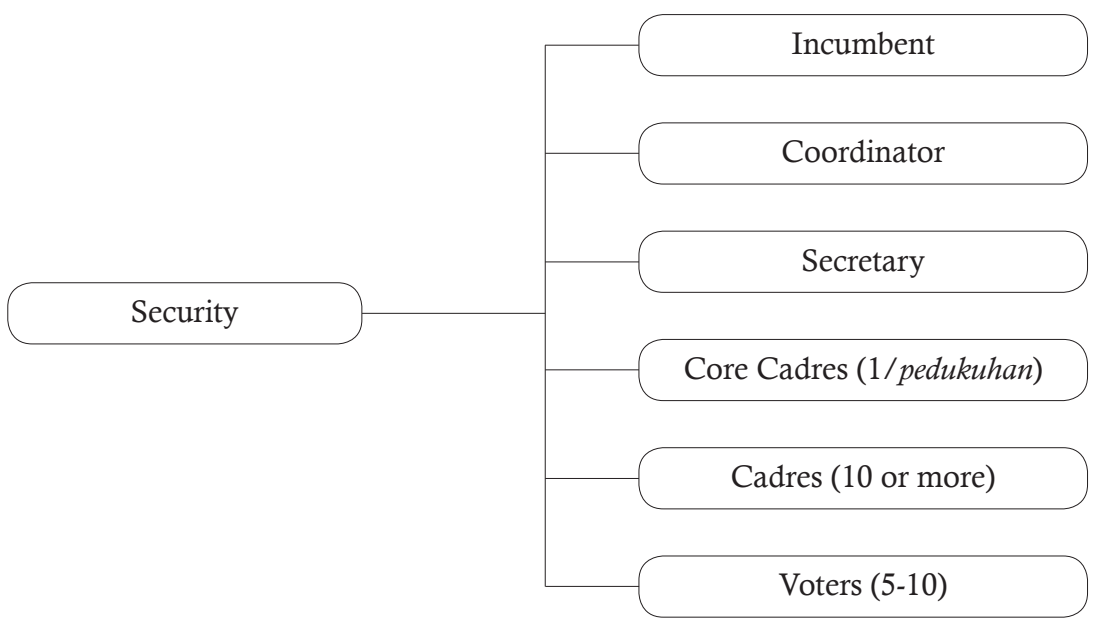

8 Interview with Aswin, 8 October 2018. 
Members of Aswin's campaign team came from a range of backgrounds. First, there were sand miners who worked at the Progo River (Anwari, interview, Oct 13, 2018) ${ }^{9}$, predominantly at the sand depots belonging to the incumbent. Aswin's sand depots had brought him significant financial and political benefits. The patron-client relationships created through these business activities provided him with the political resources that he needed to contest the 2009 and 2018 village chief elections.

Second, the village thugs (preman). Aswin's willingness to interact with people of all backgrounds, as well as his previous work as a driver, prepared him to deal with all elements of societyincluding the preman. Third, village leaders who provided a strategic means of attaining broader social support. Bariyadi, a retired soldier who had failed the village chief selection test, was among those whom Aswin approached and asked for support. Bariyadi had significant support among the people of Klangor, spread around various padukuhan, and thus his support could prove a significant boon. Although Bariyadi was also approached by Sudarmadi, and even made a coordinator of that candidate's campaign team (Mulyono, interview, Oct 13, 2018), Bariyadi still supported Aswin and invited the incumbent to campaign in his areas of influence.

Fourth, the village administration. Although village officials are legally required to be neutral in elections, some of them-including the padukuhan heads - furtively backed Aswin's campaign. The incumbent thus capitalised on relationships that he had established during his first term in office. Fifth, election committee members. This committee consisted of people from all parts of society, including youths, village administrators, and societal leaders, and many of them had established personal and working relationships with the incumbent during his first term.

The political situation in the 2018 village election differed significantly from that in 2010 (Sungkono, interview, Oct 25, 2018;

Anwari was member of Sudarmadi Campaign Team. 
Aswin, interview, Oct 9, 2018; Anwari, interview, Oct 13, 2018). In the previous election, competition had been fiercer. Meanwhile, in the 2018 election, Aswin was heavily favoured over the other candidates, who lacked the political machine and networks that the incumbent had established during his first term.

Persaingan tidak terlalu panas dibandingkan dulu. Dulu persaingan kuat dalam merangkul massa. Dulu saling menjatuhkan antar calon (The competition wasn't as heated as before. Before, my opponents were good at embracing the masses. Before, candidates took shots at each other; Aswin, interview,

Oct 9, 2018).

Despite the relative lack of competition, Aswin mobilised his political machine as soon as his campaign team had its first meeting. The campaign team and its cadres sought public support and compiled a list of village residents who were ready to support the incumbent. According to one informant, during their door-to-door campaign activities, the incumbent and his team did not offer any programmes or policies. Rather, they approached constituents and asked whether they were willing to support Aswin, then recorded their answer. Each cadre was tasked with finding 20 biting, persons who were willing to vote for the incumbent and who would thus receive money.

Aswin exercised direct control as his cadres sought voters' support. For the week before election day, the team met every night at the incumbent's home to attain victory. As in the previous election, the incumbent maintained a strong network of patron-client relationships through the politics of benevolence. For example, he attempted to improve team performance by providing each cadre with a financial incentive of $\mathrm{Rp} 50,000$ (ostensibly to pay for petrol and cigarettes). To ensure their continued loyalty, the incumbent provided all that his team members desired, including food and alcoholic beverages. The night before the election, Aswin hosted an "open house", during which he welcomed village residents as well as village chiefs from Galur District. He had used this strategy during 
the previous election, despite its significant expense (equivalent to one truck) (Aswin, interview, Oct 9, 2018).

Second, Aswin's capacity as a patron was evident in his ability to control almost all of the political spectrum in Klangor Village. Although they were legally required to be neutral, almost all members of the election committee were Aswin supporters. Indeed, several members of the committee monitored the research team's activities and conveyed this information to the incumbent. ${ }^{10}$ Aswin also exerted control over the village officials; when the research team requested important background information, for example, village staff refused to provide it, giving a number of reasons. ${ }^{11}$

Aswin's capacity as a patron was not only evident in his villagelevel activities. He was known as having established close ties with political actors and other figures at the regency and national level, as through his business activities he had interacted with people from various social backgrounds. This was confirmed when the research team first visited Aswin's home during one of his "open houses" in the week before the election. Aswin's guests came not only from Klangor Village, but also from other villages within and without Galur District.

Aswin had established strong political networks at the regency and national level. Through his working and personal relationship with members of the municipal and provincial parliament, Aswin was able to access government projects and gain financial support for Klangor. He also received financial support from several legislative candidates from the Democratic Party of Indonesia - Struggle

10 The research team's activities were continuously monitored by Aswin's staff and informants. In an interview, Aswin stated that he had been told to beware of the research team, as the team had been identified as an independent election monitor. Interview with Aswin, 8 October 2018.

11 Village administrators were unwilling to provide documents that, by law, are supposed to be publicly accessible (including the village mid-term development policy and budget), claiming that these documents were outside the scope of this research. Copies of these documents were subsequently received from Jiwan, a member of the Village Council who was politically opposed to Aswin and his alliance. 
(Partai Demokrat Indonesia -Perjuangan, PDIP). The night before the election, Aswin received numerous visitors from around Kulon Progo, including village chiefs and regency-level officials. ${ }^{12}$

Third, Aswin proved able not only to control the flow of information, but also to combat rumours. During the election, rumours circulated that the incumbent was experiencing marital problems, that he had divorced his wife and married an 18-year-old girl. ${ }^{13}$ Although this rumour was being actively spread by Aswin's political opponents, the incumbent and his campaign team were able to ensure it did not affect the election results. The campaign team, as well as a number of constituents, believed that the incumbent's family issues were solely personal, and as such of no relevance to his ability to lead Klangor.

Complementing his use of benevolence politics and economic resources, Aswin also utilised scare-off tactics to control both his followers and his opponents. For example, although his opponents were willing to use the incumbent's divorce for political purposes, arguing that it offered a poor example to the residents of Klangor, they were careful in spreading the rumour. Similarly, community members were unwilling to openly discuss the divorce, citing a mixture of fear and respect.

Aswin similarly used scare-off tactics to discipline his campaign team and his supporters, making voters think twice before "betraying" him by voting for another candidate. He similarly created fear among the village administrators who had once worked under him, excluding those whom he believed had not supported him during the 2010 election or whom he expected would betray him during the 2018 election. One informant, a village official, stated that the incumbent had stopped including him in village projects

12 Among those who visited Aswin at his home the night before the election were his peers (the village chiefs of Wonolelo and Sidorejo), as well as the chief of the Kulon Progo Municipal Police.

13 One informant stated that Aswin had been married four times, and that he was in the process of reconciling with his third wife (whom he had divorced previously). 
after he had admitted to voting for another candidate (Satiman, interview, Oct 5, 2018).

Able to adapt to various situations, Aswin proved more than capable of controlling the political spaces in the village. He used this ability in his political activities. When the research team visited Aswin at his home the night before the election, a group of "soldiers" were standing around the house, promoting the incumbent while monitoring the movements and activities of outsiders who could disrupt the election.

Fourth, the incumbent did not only establish paternalistic networks through his everyday interactions, but also through his campaign activities. In return for their support, he offered club goods to various social groups; he similarly promised that padukuhan that supported him would receive special treatment. In one padukuhan, the incumbent signed a political agreement with local residents, promising to provide a wedding stage (Luhung, interview, Oct 5, 2018; Sudarmadi, interview, Oct 8, 2018; Jiwan, interview, Oct 10, 2018; and Anwari, interview, Oct 13, 2018).

These campaign activities, as well as Aswin's vision and mission, were not enough to gather widespread public support. In Klangor, money politics has long tainted the election process, with voters generally being unwilling to support candidates who do not give them money. For example, when one candidate-known to lack financial capital—conducted door-to-door campaign activities, several residents explicitly asked him whether he would give them money (Pradana, interview, Oct 10, 2018 ${ }^{14}$ ). Unlike in the 2010 election, during which he gave money (between Rp 30,000 and $\mathrm{Rp} 50,000$ ) to voters on election day (Anwari, interview, Oct 13, 2018; Aswin, interview, Oct 9, 2018; and Luhung, interview, Oct $15,2018,{ }^{15}$ in 2018 the incumbent used a post-election approach. He promised club goods to social groups and communities, as

\footnotetext{
14 Pradana was village chief candidate.

15 Some cadres tasked with distributing money to voters unilaterally reduced the amount
} 
well as money (between Rp 50,000 and Rp 100,000) to individual voters; goods and money would only be distributed after Aswin was formally elected (Luhung, interview, Oct 15, 2018; Jiwan, interview, Oct 10, 2018).

Such a post-election strategy was made possible by two factors. First, Aswin had a strong campaign team, one that reached across the village. Without this team, it would have been difficult for the incumbent to buy votes and distribute club goods. None of the other candidates had such campaign teams (Mulyono, interview, Oct 13, 2018). Mobilising such a campaign team was an expensive venture, as money was needed to pay staff, cover their transportation costs, and purchase food. Furthermore, the incumbent exploited the popular perception that he was "one of the people" to maintain his team's loyalty and frighten off potential traitors. This team convinced voters that, even though they would not receive it immediately, they would still be given money if they voted for Aswin.

Second, as other candidates were unwilling to distribute public goods or buy votes, it was possible to entice voters with money politics. The incumbent understood his opponents abilities and capital. Unlike in the 2010 election, during which he had faced stiff competition and thus felt compelled to distribute envelopes filled with money to voters on election day, in the 2018 election he did not face serious competition. Jiwan lacked the financial capacity to use money politics and buy votes, while Pradana lacked both financial and social capital. Sudarmadi, the only other candidate with the capacity to buy votes, did not "seriously" contest the village chief election.

To ensure that voters supported Aswin on election day, his campaign team worked systematically. Five team members-one coordinator, two local witnesses, and two outside witnessesattended each polling station. Local witnesses had several duties, working not only to record who had voted and who had not voted, 
but also to work with the outside witnesses to monitor the tabulation process. Outside witnesses, meanwhile, were tasked with ensuring pledged votes were cast and reaching constituents who had yet to vote. Each witness received $\mathrm{Rp} \mathrm{50,000} \mathrm{to} \mathrm{cover} \mathrm{the} \mathrm{cost} \mathrm{of} \mathrm{lunch}$ and cigarettes.

For Aswin, money politics was a "bastard child" of sorts, something that was undesirable but nonetheless unavoidable. As such, laws that prohibited the use of money politics in village elections were pointless. This condition was exacerbated by the fact that village residents were unwilling to report cases of vote buying, fearing potential repercussions; owing to the size of the village, any whistle-blowers would be unable to avoid the wary eyes or threats of their peers. For Aswin, it was normal and expected to provide food and cigarettes to his cadres, as they had not only campaigned for him but also looked after his home when he travelled. The Rp 50,000 that Aswin paid his cadres, ultimately, was insufficient to cover the time and effort that they had put into his campaign.

Before the campaign, Aswin seriously weighed the risks of using money politics. If a cadre were caught distributing money, this could affect his inauguration as village chief.

Jika saya menang, saya mbagikan duit, tetapi teman saya ketangkap dan menjadi permasalahan sehingga saya tidak dilantik. Apakah teman saya tidak marah? Apakah saya tidak lebih marah dari teman saya? sedangkan teman-teman saya banyak. Saya sampai matipun akan membalas dendam pada yang melaporkan (If I were to win, and I were to distribute money, but one of my cadres were caught distributing money, and this resulted in problems and I were not inaugurated, wouldn't my cadre be upset? Wouldn't I be more upset? And I have many friends... I would swear vengeance on any tattle-tales, until the day I died; Aswin, interview, Oct 9, 2018).

The incumbent thus decided to postpone distributing money to voters until after the election, thereby transforming his pre-election vote buying strategy into a post-election one. This decision suggests that, in the election, money did not simply represent a transaction between a patron (candidate) and client (voter) in Klangor's 2018 
election. Rather, it was appreciative, a reward provided to voters in exchange for their support. This suggests a sophisticated approach to politics, one that not only minimises risks but also transforms how money is understood.

The paternalistic networks that Aswin had established through his everyday interactions as well as during his campaign enabled him to win the election, receiving 1,529 votes $(51.41 \%$ of all valid votes) ${ }^{16}$ Of the seven polling stations in Klangor, the incumbent won five. Although he lost Polling Station 2 (Gebang - Klangor) and Polling Station 5 (Curup Kidul - Minggir), which were won by the local candidate (Jiwan and Sudarmadi, respectively), he had a significant showing. Ultimately, the incumbent's electoral victory was predicted several days before votes were cast, as he had the strongest political machine and most economic and social capital.

\section{Conclusion}

Ultimately, several conclusions may be drawn from the arguments above, as well as this article's narrative of Aswin's electoral victory in Klangor's 2009 and 2018 elections:

First, patronage remains an effective means for local politicians to gain power and become important political actors. Leading the lowest level of government, village chiefs are expected to establish paternalistic networks. Uniquely, their patronage is not simply derived from the practice at higher levels (i.e. in legislative and municipal elections), but rather maintained through the everyday interactions required to successfully lead the village government. As patrons, village chiefs have numerous social obligations; they must provide protection, distribute resources, and act benevolently to retain the trust and loyalty of their constituents and entice new

16 A total of 2,974 votes were cast in the election, consisting of 2,844 valid votes, 130 invalid votes, and 8 additional votes. The incumbent won the election, receiving more votes than Giharto (102 votes; $3.43 \%$ of valid votes), Jiwan (611; 20.54\%), Pradana (177; $5.95 \%$ ), and Sudarmadi $(425 ; 14.29 \%)$. Data received from the Klangor Village Election Committee. 
voters.

In Klangor, the incumbent relied on his significant economic capital to act as a patron. Using the considerable financial resources available to him, the incumbent practiced benevolence politics in both his formal (i.e. government) and informal interactions with his constituents. He was egalitarian, making friends with people from diverse backgrounds. At the same time, however, he reinforced his position by using scare-off tactics to discipline his cadres, avoid potential treachery, ensure village officials' support, and minimise the possibility that his vote buying activities would be reported.

Second, the patron-client relationships that have long characterised village communities are no longer rooted in land ownership and kinship networks, but rather in a modern form of economic capital: money. Patronage ultimately leads to money politics, vote buying, and the provision of club goods. As seen in Aswin's 2010 and 2018 electoral campaigns, vote buying can take various forms. In 2010, when the election was fiercely contested by candidates with similar abilities and resources, votes were bought before the election. Conversely, in 2018, when Aswin was favoured to win the election and other candidates lacked the economic capital to buy votes, it was possible for him to wait until after the election to distribute money and club goods. This post-election approach to vote buying also allowed the incumbent to mitigate the possibility of his activities - prohibited by law-being reported to an election monitoring body.

\section{Acknowledgements}

This article was written as part of a research project conducted by the Research Centre for Politics and Government (PolGov), Department of Politics and Government, Faculty of Social and Political Sciences, UGM, in conjunction with the Australian National University (ANU), Australia, and KITLV, Netherlands. Field research was conducted over the course of one month, 
covering the two weeks before the village election and the two weeks after the election, in a village in Kulon Progo Regency, Special Administrative Region of Yogyakarta. To maintain confidentiality, the informants and locations mentioned in this article have been pseudonymised. All information, data, and arguments in this article are entirely those of the authors. 


\section{References}

Andhika, L. R. (2017). Bahaya patronase dan klientelisme dalam pemilihan kepala desa serentak. Kajian 22(3), 205-219.

Aspinall, E., \& As'ad, M. U. (2015). The patronage patchwork: Village brokerage networks and the power of the state in an Indonesian election. Bijdragen tot de Taal-, Land-en Volkenkunde, 171(2/3), 165195.

Aspinall, E., \& Sukmajati, M. (2015). Politik uang di Indonesia; Patronase dan klientelisme pada Pemilu Legislatif 2014. Yogyakarta: PolGov.

Berenschot, W. (2018). The political economy of clientelism: A comparative study of Indonesia's patronage democracy. Comparative Political Studies 51(12), 1-31.

Buve, R. (1992). Political patronage and politics at the village level in Central Mexico: Continuity and change in patterns from the late colonial period to the end of the French intervention (1867). Bulletin of Latin American Research 11(1), 1-28.

Cox, G.W. \& Katz, J.N. (1996). Why did the incumbency advantage in U.S. house elections grow? American Journal of Political Science, 40(2), 478-497.

Eisenstadt, S. \& Roniger, L .(1984) Patrons, clients and friends: Interpersonal relations and the structure of trust in society. Cambridge University Press.

Endraswara, S. (2013). Falsafah kepemimpinan Jawa: Butir-butir nilai yang membangun karakter seorang pemimpin menurut budaya Jawa. Yogyakarta: NARASI.

Fikri, H. (2017). The practice of political patronage and clientelism of the Democrat Party in the 2014 legislative election in Ponorogo Regency. Journal of Government \& Politics, 8(4), 467-492.

Gallego, J., Li, C., \& Wantchekon, L. (2018). The political economy of patrons, brokers, and voters. Serie Documentos De Trabajo, 219, 1-23.

Grzymala-Busse, A. (2008). Beyond clientelism: Incumbent state capture and state formation. Comparative political studies, 41(4-5), 638-673. doi:10.1177/0010414007313118

Hanif, H. (2009). Politik klientelisme baru dan dilema demokratisasi di Indonesia. Jurnal Sosial \& Politik, 12(3), 348-349.

Hopkin, J. (2006). Conceptualizing political clientelism: Political exchange and democratic theory. Paper prepared for APSA annual meeting, Philadelphia, 31 August - 3 September 2006. 
Khusni, D. A., Sardini, N. H., \& Kushandayani (2018). Politik uang dan patronase dalam pemilihan kepala desa (Pilkades) Cangakan Kecamatan Kasreman Kabupaten Ngawi Provinsi Jawa Timur Tahun 2013. Journal of Politics and Government Studies, 7(1), 181190

Klinken, G. v. (2009). Patronage democracy in provincial Indonesia. In O. Tornquist, N. Webster, \& K. Stokke (eds.), Rethinking popular representation (pp. 141-159). London: Palgrave Macmillan.

Latief, H. (2013a). Islam and humanitarian affairs: The middle class and new patterns of social activism. In K. v. Dijk \& J. Burhanuddin (eds.), Islam in Indonesia: Contrasting images and interpretations (pp. 173-194). Amsterdam: Amsterdam University Press.

Latief, H. (2013b). The politics of benevolence: Political patronage of party-based charitable organizations in contemporary Indonesian Islam. Al-Jami'ah, 51(2), 337-363

Lindberg, S.I (2003). 'It's our time to "chop"': Do elections in Africa feed neo-patrimonialism rather than counter-act it? Democratization, 10(2), 121-140.

Mason, T. D. (1986). Land reform and the breakdown of clientelist politics in E1 Salvador. Comparative Political Studies, 18(4), 487-516.

Pappas, T. S. (2009). Patrons against partisans: The politics of patronage in mass ideological parties. Party Politics, 15(3), 315-334

Piattoni, S. (2001). Clientelism, interests, and democratic representation: the European experience in historical and comparative perspective. Cambridge University Press.

Prijono M., Yumiko, \& Tjiptoherijanto. (1983). Demokrasi di pedesaan Jawa. Jakarta: Sinar Harapan.

Ramli, M. (2016) Patronase politik dalam demokrasi lokal (Analisis terhadap terpilihnya Hj. Marniwati pada Pemilukades di Desa Jojjolo Kecamatan Bulukumpa Kabupaten Bulukumba). Unpublished undergraduate thesis, Makassar State Islamic University.

Shin, J. H. (2015). Voter demands for patronage: Evidence from Indonesia. Journal of East Asian Studies, 15 (1), 127-151.

Simandjuntak, D. (2015). Persistent patronage: Explaining the popularity of former corruption convicts as candidates in Indonesia's regional elections. Perspective, 55, 1-10.

Tomsa, D., \& Ufen, A. (2013). Party politics in Southeast Asia: Clientelism and electoral competition in Indonesia, Thailand and the Philippines. New 
York: Routledge.

Weingrod, A. (1968). Patrons, patronage, and political parties. Comparative Studies in Society and History, 10(4), 377-400. 